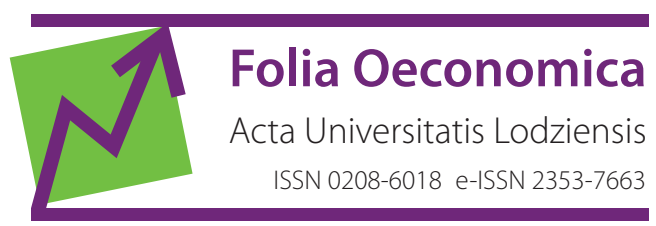

www.czasopisma.uni.lodz.pl/foe/

5(344) 2019

DOI: http://dx.doi.org/10.18778/0208-6018.344.03

\title{
Katarzyna Cheba
}

West Pomeranian University of Technology in Szczecin, Faculty of Economics

Department of Applied Mathematics in Economics, katarzyna.cheba@zut.edu.pl

\section{Iwona Dorota Bąk}

West Pomeranian University of Technology in Szczecin, Faculty of Economics

Department of Applied Mathematics in Economics, iwona.bak@zut.edu.pl

\section{The Application of Multi-Criteria Taxonomy to Comparative Analysis of Structures of Sustainable Development}

\begin{abstract}
One of the most common errors in research on sustainable development is to analyse a set of features describing this development within one set of diagnostic features. Such an approach does not allow for examining the real changes taking place within each area of sustainable development. These changes may have a completely different direction in the case of indicators describing, for example, the economic area or the environmental area of sustainable development. The solution is to consider the indicators separately for each area and then compare the results obtained. In this work, multi-criteria taxonomy was used for this purpose. The study used indicators published by Eurostat to monitor progress in implementing the Agenda for Sustainable Development 2030 from 2008 and 2016. The results presented in the paper confirmed the considerable diversity of the EU countries in each area of sustainable development and their large heterogeneity.
\end{abstract}

Keywords: sustainable development, multi-criteria taxonomy, European Union

JEL: C38, O11, P36 


\section{Introduction}

The current stage in the development of the concept of sustainable development is defined in the literature (Sexton, Barrett, Lu, 2008; Borys, Czaja, 2009; Płachciak, 2011) as the concretisation of the new paradigm of development. This instantiation is performed in many different areas including: features, principles, objectives and examples that are considered as strategic benchmarks for sustainable development. This is also important when the concept of measurement of this phenomenon is developed. The existing proposals for the quantitative assessment of the progress made in implementing sustainable development are dominated by the approach under which, on the basis of indicators that describe different areas of development (the economic, social and environmental ones), one synthetic measure is constructed in order to describe the changes that occur in these areas at the same time (Kondyli, 2010; Sébastien, Bauler, 2013; Talukder, Hipel, van Loon, 2017; Guijarro, Poyatos, 2018). However, this approach does not enable us to analyse the internal structure of this development, which is often created by completely different results achieved within each area. In many cases, it may also distort the obtained results, e.g. in the case of economically developed countries of the world simultaneously exerting a stronger pressure on the environment, which, as a result of combining features describing various dimensions of sustainable development, may achieve even much better results than in the case of economically weaker countries, and at the same time less pollution of the natural environment.

Whereas the implementation of sustainable development should assume, in accordance with the strong principle of durability of development, which is considered to be one of the most important rules, the preservation of different types of capital: economic, social and environmental capital treated separately. This principle is also supplemented by: the principle of the integrity understood as the consistent and simultaneous creation of individual areas and the principle of generational justice in access to environment (intra- and inter-generational and allowable environmental capacity) (Borys, 2005).

From another point of view, it is worth noting that, in the recent years, many methods and indicators have been elaborated to measure sustainable development in various areas. Areas such as: sustainable agriculture (Velten et al., 2015), sustainable cities (Zhao, 2011), sustainable financing (Jeucken, 2011), and even a whole new area of sustainable competitiveness of the national economy (Aiginger, Bärenthaler-Sieber, Vogel, 2013) are already presented in the literature. The results of these studies are usually treated as complementary to the analysis of the main areas of sustainable development. They are developed on the basis of a more traditional understanding of the sustainable development idea. It means that they should be treated as a very important direction of development of the main idea but their connection with this idea is mainly complementary. The main compo- 
nents of sustainable development are: social, economic and environmental pillars (orders). These pillars will form the basis of the analyses presented in the paper.

The last two decades have seen a proliferation of methods and indicators to measure sustainable development. A number of composite indicators have been proposed in the academic literature, and many national statistical offices have adopted sets of sustainable development indicators to track progress towards a sustainable society. While these initiatives have helped to put sustainable development on the agenda of national and international institutions, the differences between the approaches remain large. Therefore, the Conference of European Statisticians (CES) set up in 2009 a joint United Nations Economic Commission for Europe (UNECE), European Commission (Eurostat) and Organisation for Economic Co-operation and Development (OECD) Task Force to develop recommendations aiming to harmonise different ways in which sustainable development was being measured. The Task Force followed up on the work of the previous UNECE/ Eurostat/OECD Working Group on this topic which resulted in the publication "Measuring Sustainable Development" produced in 2009.

It should also be considered that at the present stage of the implementation of the objectives set up in different strategies of sustainable development, including in particular in the latest global strategy for Sustainability 2030 (2030 Agenda), we have to deal with a significant differentiation of the obtained results in various countries of the world. It is also visible in the case of the European Union, despite the integration of countries whose accession to the European Community requires the fulfilment of specific developmental criteria. This considerable variation is also reflected in the values of individual indicators for monitoring the achievement of the objectives of this Agenda. For this reason, the measurement of sustainable development, in addition to the indicated separate analysis of changes occurring in the distinguished areas, should also be made using methods which allow us to eliminate the impact of possible outliers on the results of the order and classification obtained.

In the literature (see: Leonard et al., 2006; Andersen, 2008; Holm Olsen, Fenhann, 2008), the areas of sustainable development are usually considered separately or they were treated as components of the main taxonomic measure of development. This way of analysis has not allowed us to indicate the countries in which sustainable development has the same direction of changes in every considered areas. According to the authors, taking into account the main principles of sustainable development, there exists the need to find more precise methods in this field.

The aim of the paper is the comparative analysis of the results of the arrangement and classification of countries of the European Union, covering the changes taking place in various areas of the sustainable development structure. In accordance with the adopted assumption and in order to achieve thus formulated objective, the research procedure consisting of two steps was implemented. Under the first of them, the examined EU countries were sorted out due to the level of devel- 
opment achieved by these countries on the basis of features describing particular areas of sustainable development. For this purpose, a comparison was performed comparing the results obtained while building development taxonomy measures according to the zero unitarisation method (Kukuła, 2000: 60-92) and a method more resistant to outliers based on Weber' median vector (Weber, 1971) described in the following papers: Lira, Wagner and Wysocki (2002), Młodak (2006). In the second stage, to divide the surveyed EU countries into a class characterised by similarity within each of the highlighted areas, the method of multi-criteria taxonomy was applied. The bases for the analysis of development within each of the highlighted areas are the values of the indicators to monitor progress in the implementation of the objectives of the Agenda for 2030.

The article is divided into six parts. The first one presents the main assumptions of the presented analyses and the purpose of the research. In the next part, the statistical data being the subject matter of the research presented in the paper is presented. The third part is dedicated to the description of the mathematical methods used. The fifth part shows the results of the research, and the sixth formulates conclusions and directions of further studies.

The value added of the analysis presented in this paper is the assessment of the level of sustainable development of the EU Member States in each area of this development based on the comparison of the methods proposed by the authors.

\section{Agenda 2030 as a basis for statistical data for the analysis of sustainable development}

Indicators used by the European Commission to monitor progress in the implementation of the "Agenda for Sustainable Development 2030" in the European Union in 2016 are the basis of empirical analyses presented in this paper. In the schedules provided by Eurostat (2018), there are currently 100 indicators describing 17 goals of Agenda 2030 ( 51 of them are a part of a global list of indicators of the United Nations - the UN, the others were chosen in a way enabling us to monitor the direction of changes in accordance with the relevant policies and initiatives of the EU). Each goal is monitored by up to 6 different indicators. It is also worth noting that some of them are only available at the level of the European Union as a whole, and, in the case of indicators describing the protection of the seas - the data are available only for countries which have access to the sea. This is the reason for the restriction of the original list of 100 indicators of the Agenda 2030 to 65 indicators available for all analysed EU countries.

In the paper, these indicators have been attributed to three main areas of sustainable development: the economic, social and environmental ones, and addition- 
ally to the institutional and political area which has been separated from the indicators describing the social area of sustainable development. The decision on the separation of this area was taken due to its particular role for the operation, development and further integration of the Member States of the European Union. Thus, the divided indicators allow us to monitor changes to sustainable development in a more universal way, relating not only to the currently formulated strategic objectives, which are always the result of a compromise between countries that accept a given development strategy, but also to the fundamentals of the very idea of this development.

The method of reverse matrix coefficients of correlation (Malina, Zeliaś, 1998; Lira, Wagner, Wysocki, 2002; Malina, 2004: 139-147; Młodak, 2006) was applied to the selection of diagnostic characteristics within each of the highlighted areas. In this method, on the basis of Pearson correlation coefficients matrix $(\mathbf{R})$, the inverse matrix of the $\mathbf{R}^{-1}$ to this matrix is established. The diagonal elements of the matrix $\mathbf{R}^{-1}$ take values from the interval $[1, \infty]$. In the situation when the considered features do not create many exact interdependencies, its diagonal elements are defined as Variance Inflation Factor - VIF, which are determined for given features in comparison to others. However, if these elements are too large (it is usually assumed that these values are greater than 10), this means a faulty numerical conditioning of $\mathbf{R}^{-1}$ matrix, i.e. excessive correlating of a given feature with other ones, which should be eliminated from further analysis. These features can be eliminated gradually (Cheba, 2019), just as in the Hellwig parameter method (Hellwig, 1968), the aim in this case is to prevent the excessive information resource diminishing of the model.

Such a selection method results in four sets of diagnostic features covering: 15 indicators that describe the economic sustainable development area, 17 indicators highlighted in the framework of the social area and 8 indicators in the environmental area, as well as 8 indicators in the institutional and political area. The $x_{i, j}$ symbol is assigned to each of the highlighted features, where $i$ is the number of the area in which the feature is located, while $j$ is the number of the feature (Table 1). Moreover, their influence on the analysed phenomenon was established through the classification of each indicator to a set of features stimulating development in a given area (symbol $S$ ) or destimulating this development (symbol $D$ ).

Table 1. Statistical data

\begin{tabular}{|l|l|}
\hline Symbol & \multicolumn{1}{|c|}{ The economic area of sustainable development } \\
\hline$x_{1.1 S}$ & Agricultural factor income per annual work unit (AWU), chain linked volumes \\
\hline$x_{1.2 S}$ & Government support to agricultural research and development, Euro per capita \\
\hline$x_{1.3 S}$ & Area under organic farming, \% of utilised agricultural area \\
\hline
\end{tabular}




\begin{tabular}{|c|c|}
\hline$x_{1.4 D}$ & $\begin{array}{l}\text { Inactive population due to caring responsibilities, } \% \text { of inactive population aged } 20 \\
\text { to } 73\end{array}$ \\
\hline$x_{1.5 S}$ & Real GDP per capita, chain linked volumes (2010), Euro per capita \\
\hline$x_{1.6 D}$ & $\begin{array}{l}\text { Young people neither in employment nor in education and training \% of population } \\
\text { aged } 15 \text { to } 38\end{array}$ \\
\hline$x_{1.7 D}$ & Involuntary temporary employment, \% of employees aged 20 to 73 \\
\hline$x_{1.8 D}$ & People killed in accidents at work, number per 100000 employees \\
\hline$x_{1.9 S}$ & Gross domestic expenditure on R\&D, \% of GDP \\
\hline$x_{1.10 S}$ & $\begin{array}{l}\text { Employment in high- and medium-high technology manufacturing sectors and } \\
\text { knowledge-intensive service sectors, \% of total employment }\end{array}$ \\
\hline$x_{1.11 S}$ & Purchasing power adjusted GDP per capita, real expenditure per capita (in PPS) \\
\hline$x_{1.12 S}$ & $\begin{array}{l}\text { Resource productivity and domestic material consumption (DMC), Euro per } \\
\text { kilogram, chain linked volumes (2010) }\end{array}$ \\
\hline$x_{1.13 D}$ & Volume of freight transport relative to GDP, index $(2005=100)$ \\
\hline$x_{1.14 D}$ & General government gross debt, Percentage of gross domestic product (GDP) \\
\hline$x_{1.15 S}$ & Shares of labour taxes in total tax revenues, $\%$ of total taxes \\
\hline Symbol & The social area of sustainable development \\
\hline$x_{2.1 D}$ & $\begin{array}{l}\text { People living in households with very low work intensity, \% of total population aged } \\
\text { less than } 78\end{array}$ \\
\hline$x_{2.2 D}$ & Housing cost overburden rate by poverty status, $\%$ of population \\
\hline$x_{2.3 D}$ & $\begin{array}{l}\text { Population living in a dwelling with a leaking roof, damp walls, floors or foundation } \\
\text { or rot in window frames of floor, \% of population }\end{array}$ \\
\hline$x_{2.4 S}$ & Self-perceived health, very good or good, $\%$ of population \\
\hline$x_{2.5 D}$ & Suicide rate by sex, number per 100000 persons \\
\hline$x_{2.6 D}$ & $\begin{array}{l}\text { Self-reported unmet need for medical care by detailed reason, } \% \text { of population aged } \\
16 \text { and over }\end{array}$ \\
\hline$x_{2.7 D}$ & Early leavers from education and training by sex, \% of population aged 18 to 33 \\
\hline$x_{2.8 S}$ & Tertiary educational attainment, $\%$ of population aged 30 to 43 \\
\hline$x_{2.9 S}$ & Adult participation in learning, $\%$ of population aged 25 to 73 \\
\hline$x_{2.10 D}$ & Population unable to keep home adequately warm, \% of population \\
\hline$x_{2.11 S}$ & Long-term unemployment rate, $\%$ of active population \\
\hline$x_{2.12 S}$ & Relative median at-risk-of-poverty gap, \% distance to poverty threshold \\
\hline$x_{2.13 D}$ & Overcrowding rate, $\%$ of population \\
\hline$x_{2.14 D}$ & $\begin{array}{l}\text { Population living in households considering that they suffer from noise, } \\
\% \text { of population }\end{array}$ \\
\hline$x_{2.15 D}$ & People killed in road accidents, rate \\
\hline$x_{2.16 D}$ & Death rate due to homicide, number par 100000 persons \\
\hline$x_{2.17 D}$ & $\begin{array}{l}\text { Population reporting occurrence of crime, violence or vandalism in their area, } \\
\% \text { of population }\end{array}$ \\
\hline
\end{tabular}




\begin{tabular}{|l|l|}
\hline Symbol & \multicolumn{1}{|c|}{ The environmental area of sustainable development } \\
\hline$x_{3.1 D}$ & Ammonia emissions from agriculture, kilograms per hectare \\
\hline$x_{3.2 D}$ & Primary energy consumption, million tonnes of oil equivalent (TOE) \\
\hline$x_{3.35}$ & Energy productivity, Euro per kilogram of oil equivalent (KGOE) \\
\hline$x_{3.4 S}$ & Share of renewable energy in gross final energy consumption, $\%$ \\
\hline$x_{3.5 D}$ & Energy dependence \% of imports in total energy consumption \\
\hline$x_{3.65}$ & Recycling rate of municipal waste, \% of total waste generated \\
\hline$x_{3.7 D}$ & Greenhouse gas emissions - tonnes per capita \\
\hline$x_{3.8 D}$ & $\begin{array}{l}\text { Shares of environmental taxes in total tax revenues, \% of total taxes, Total } \\
\text { environmental taxes }\end{array}$ \\
\hline Symbol & \multicolumn{1}{|c|}{ The political and institutional area of sustainable development } \\
\hline$x_{4.15}$ & Seats held by women in national parliaments \% of seats \\
\hline$x_{4.2 S}$ & Seats held by women in national governments, \% of seats \\
\hline$x_{4.3 S}$ & $\begin{array}{l}\text { Positions held by women in senior management positions, board members, } \\
\% \text { of positions }\end{array}$ \\
\hline$x_{4.4 S}$ & General government total expenditure on law courts, Euro per inhabitant \\
\hline$x_{4.5 S}$ & Population with confidence in EU institutions European Parliament \% of population \\
\hline$x_{4.6 S}$ & $\begin{array}{l}\text { Population with confidence in EU institutions by institution, European Central Bank, } \\
\% \text { of population }\end{array}$ \\
\hline$x_{4.75}$ & $\begin{array}{l}\text { Official development assistance as share of gross national income, \% of gross national } \\
\text { income (GNI) }\end{array}$ \\
\hline$x_{4.8 S}$ & $\begin{array}{l}\text { EU imports from developing countries by country income groups, million EUR } \\
\text { per capita }\end{array}$ \\
\hline
\end{tabular}

Source: Eurostat, 2018

\section{Research methodology}

In accordance with the adopted assumptions, the EU Member States were divided into groups of countries similar in all distinguished areas of sustainable development. A research procedure consisting of two stages was applied for this purpose. The first stage consisted of the arrangement of EU countries in terms of the level of development achieved in each of these areas on the basis of the diagnostic features that describe each of the highlighted areas of sustainable development, using the following methods:

1. Method I - the zero unitarisation method (Kukuła, 2000: 60-92), in which the normalisation of the diagnostic features proceeds according to the following formulas: 
- for the stimulant $\quad z_{i j}=\frac{x_{i j}-\min _{i} x_{i j}}{\max _{i} x_{i j}-\min _{i} x_{i j}}, \max _{i} x_{i j} \neq \min _{i} x_{i j}$;

- for the destimulant $z_{i j}=\frac{\max _{i} x_{i j}-x_{i j}}{\max _{i} x_{i j}-\min _{i} x_{i j}}, \max _{i} x_{i j} \neq \min _{i} x_{i j}$.

Based on features transformed according to the following patterns (1-2), the taxonomic measure of development was calculated (Nowak, 1990: 130-135):

$$
z_{i}=\frac{1}{K} \sum_{k=1}^{K} z_{i k}
$$

where: $z_{i}$ - the value of the taxonomic measure of development for the $i$-th object, $z_{i k}$ - the normalised value of the $i$-th feature in the $k$-th object, $k$ - the number of features.

2. Method II - the taxonomic measure of development based on the Weber (1971) median vector (Lira, Wagner, Wysocki, 2002; Młodak, 2006; Bąk, Szczecińska, 2014), in which the normalisation is based on a quotient of the feature value deviation from the proper coordinate of the Weber median and a weighted absolute median deviation, using the Weber median according to the following formula:

$$
z_{i j}=\frac{x_{i j}-\theta_{0 j}}{1.4826 \cdot m a \tilde{a}\left(X_{j}\right)},
$$

where: $\theta_{0}=\left(\theta_{01}, \theta_{02}, \ldots, \theta_{0 M}\right)$ is the Weber median, is the absolute median deviation, in which the distance from the features to the Weber vector is measured ${ }^{1}$, i.e.:

$$
m \tilde{a} d\left(X_{j}\right)=\operatorname{med}_{i=1,2, \ldots, n}\left|x_{i j}-\theta_{0 j}\right|
$$

where: $j=1,2, \ldots, m$.

The synthetic measure $\mu_{i}$ is calculated on the basis of maximum values of normalised features, similarly to the Hellwig (1968) method:

$$
\varphi_{j}=\max _{i=1,2, \ldots, n} z_{i j}
$$

according to the following formula:

$$
\mu_{i}=1-\frac{d_{i}}{d_{-}}
$$

1 The Weber median was calculated in R program: llmedian of package: $p c a P P$. 
where: $d_{-}=\operatorname{med}(\mathrm{d})+2.5 \operatorname{mad}(\mathrm{d})$, where $\mathrm{d}=\left(d_{1}, d_{2}, \ldots, d_{n}\right)$ is a distance vector calculated using the formula:

$$
d_{i}=\operatorname{med}_{j=1,2, \ldots, m}\left|z_{i j}-\varphi_{j}\right|
$$

where: $i=1,2, \ldots, n, \varphi_{j}$ - the $i$-th coordinate of the development pattern vector which is composed of the maximum values of the normalised features.

The decision on the selection of the presented methods for the construction of the ranking list of the EU countries was taken due to the significant diversity of diagnostic features that describe the specific areas of sustainable development and their very high asymmetry. The application of positional measure of development should reduce the effect of outliers on the obtained arrangement results and in the next step also on the results of the classification of the EU countries in terms of similarities in any of the highlighted areas.

In the next stage of the research, multi-criteria taxonomy (Nowak, 1990: 130-135; Malina, 2004: 139-147; Bąk, Szczecińska, 2014) was applied to the division of the EU Member States into classes characterised by similarity in each of the analysed areas of sustainable development. The procedure implemented in this method includes the following stages:

1. On the basis of the diagnostic characteristics standardised according to presented formulas (formulas 1-2 and 3), a distance matrix is established. In the paper, the following formulas were used for this purpose:

a) in the case of the standardisation carried out in accordance with the method of zero unitarisation (formulas 1-2) - the Euclidean distance:

$$
\operatorname{distance}\left(x_{i j}, x_{k j}\right)=\sqrt{\frac{1}{m} \sum_{j=1}^{m}\left(x_{i j}-x_{k j}\right)^{2}} \text {, }
$$

b) in the case of the positional normalisation (formula 3), the median distance:

$$
\operatorname{distance}\left(x_{i j}, x_{k j}\right)=\operatorname{med}_{j=1,2, \ldots, m}\left|x_{i j}-x_{k j}\right| .
$$

2. In the next step, a threshold value is defined for distance $d^{*}$. The value is usually defined in accordance with the following formula:

$$
d^{*}=\min _{i} \max _{j}\left\{d_{i j}\right\} .
$$

3. For each classification criterion, the $\mathbf{C K}$ affinity matrix of $(n \times n)$ dimension is defined, whose elements $c_{i j}^{K}(i, j=1, \ldots, n)$ are equal to: 


$$
\begin{aligned}
& c_{i j}^{K}=1 \text { for } d_{i j} \leq d^{*}, \\
& c_{i j}^{K}=0 \text { for } d_{i j}>d^{*} .
\end{aligned}
$$

If inequality $d_{i j} \leq d^{*}$ is satisfied, the objects designated as $i$ and $j$ are deemed as similar in terms of the examined criterion. If, however, the opposite condition is satisfied, the relevant objects are treated as dissimilar for value $d^{*}$, thus the affinity measure of $c_{i j}$ will equal zero.

4. The final $\mathbf{C}_{(n \times m)}$ affinity matrix is determined among the analysed units. $c_{i j}$ elements of $\mathbf{C}$ matrix are equal to the product of relevant elements of $\mathbf{C K}$ matrix for all the analysed criteria, i.e.:

$$
c_{i j}=\prod_{K=1}^{r} c_{i j}^{K} .
$$

It means that $c_{i j}=1\left(i, j=1, \ldots, n\right.$, if each of $c_{i j}^{K}$ elements corresponding to it in CK matrices is equal to one, and $c_{i j}=0$, if at least one of the $c_{i j}^{K}$ elements corresponding to it is equal to zero. According to the above, two objects are considered to be similar to each other simultaneously on account of all the criteria, if they are similar to each other separately on account of those individual criteria. On the other hand, two objects are considered to be dissimilar on account of all the examined criteria if they are not similar to each other even on account of one of such criteria. The adoption of a given algorithm may lead to determining a large number of small sized groups (one- and two-element groups). It can then be assumed that the elements of $\mathbf{C}$ matrix are equal to 1 , if the sum of corresponding elements of $\mathbf{C K}$ affinity matrix for individual criteria is at least equal to $3 / 4$ of the sum of all differentiated criteria. Otherwise, the elements of $\mathbf{C}$ matrix are equal to zero (Malina, 2004: 145).

5. Groups of similar elements are classified and identified in terms of the examined criteria using e.g. the vector elimination method to that aim (Panek, 2009: 154-160; Malina, 2004: 60-62). A starting point for the method is a change of the final $\mathbf{C}_{(n \times n)}$ affinity matrix into a $\mathbf{C}_{(n \times n)}^{*}$ dissimilarity matrix. The course of the above-mentioned method is as follows:

a) on the basis of $\mathbf{C}^{*}$ matrix, ac column vector is created with $n$ components, each of which is a sum of the previous row of that matrix,

b) the row is eliminated from the $C^{*}$ matrix along with a corresponding column for which $\boldsymbol{c}_{0}$ vector component has a maximum value; if $\boldsymbol{c}_{0}$ vector contains several components whose value reaches maximum, such a row and column are eliminated, for instance, the one of the lowest or highest number,

c) the activities presented in sub-points a) and b) are repeated until such time when $\boldsymbol{c}_{0}$ vector components are equal to zero, 
d) the objects corresponding to the rows and columns that have not been crossed off and still remain in the $\mathbf{C} *$ matrix form the first sub-group,

e) the $\mathbf{C} *(1)$ matrix and $\boldsymbol{c}_{0}(1)$ vector are created for the remaining (eliminated) objects, then using the procedure described in sub-points a) through d) we arrive at subsequent groups of objects similar in terms of their structure, and the procedure ends once all the elements from the basic set have been grouped.

\section{Results and discussion}

Table 2 presents the values of taxonomic measures of development obtained as a result of applying both proposed approaches.

In view of the fact that the results of the analyses presented in the paper are part of a larger research project which analysed changes of sustainable development taking place in the EU countries in the years 2008-2016, in the compilations presented in the paper, Croatia is not included due to the fact that it was not a member of the European Union until $1^{\text {st }}$ July, 2013 and that deficiencies were identified in the data for the years before its accession to the European Community.

Analysing the results obtained by individual EU countries in the created ranking lists, it is worth indicating significantly better results of the most economically developed countries in the following areas: the economic, social as well as political and institutional ones, and definitely worse results in the environmental area. This situation primarily concerns the countries in Western Europe: Belgium, Germany, Luxemburg, Malta and the Netherlands. To a lesser extent, it also applies to economically developed countries in Northern Europe. Countries such as: Denmark, Finland or Sweden achieved high scores in all the analysed areas. In this case, it was possible to overcome the negative impact of the economic development of these countries on the quality and pollution of the natural environment. However, the reverse situation is observed in the case of the least economically developed countries in Eastern Europe, where low economic development results correspond to much better results in the environmental area. This situation concerns predominantly such countries as: Bulgaria, Hungary, Poland and Romania.

Because the ranking lists of countries created with the use of synthetic classical and positional measure are not the same, and in some cases vary quite significantly, in order to determine to what extent there is an ordering compliance of researched objects, Kendall's tau correlation coefficients were established (Table 3$)^{2}$.

2 Kendall tau coefficients take values in the range [-1.1]. The closer to 1 is the value, the greater the ordering compliance. 


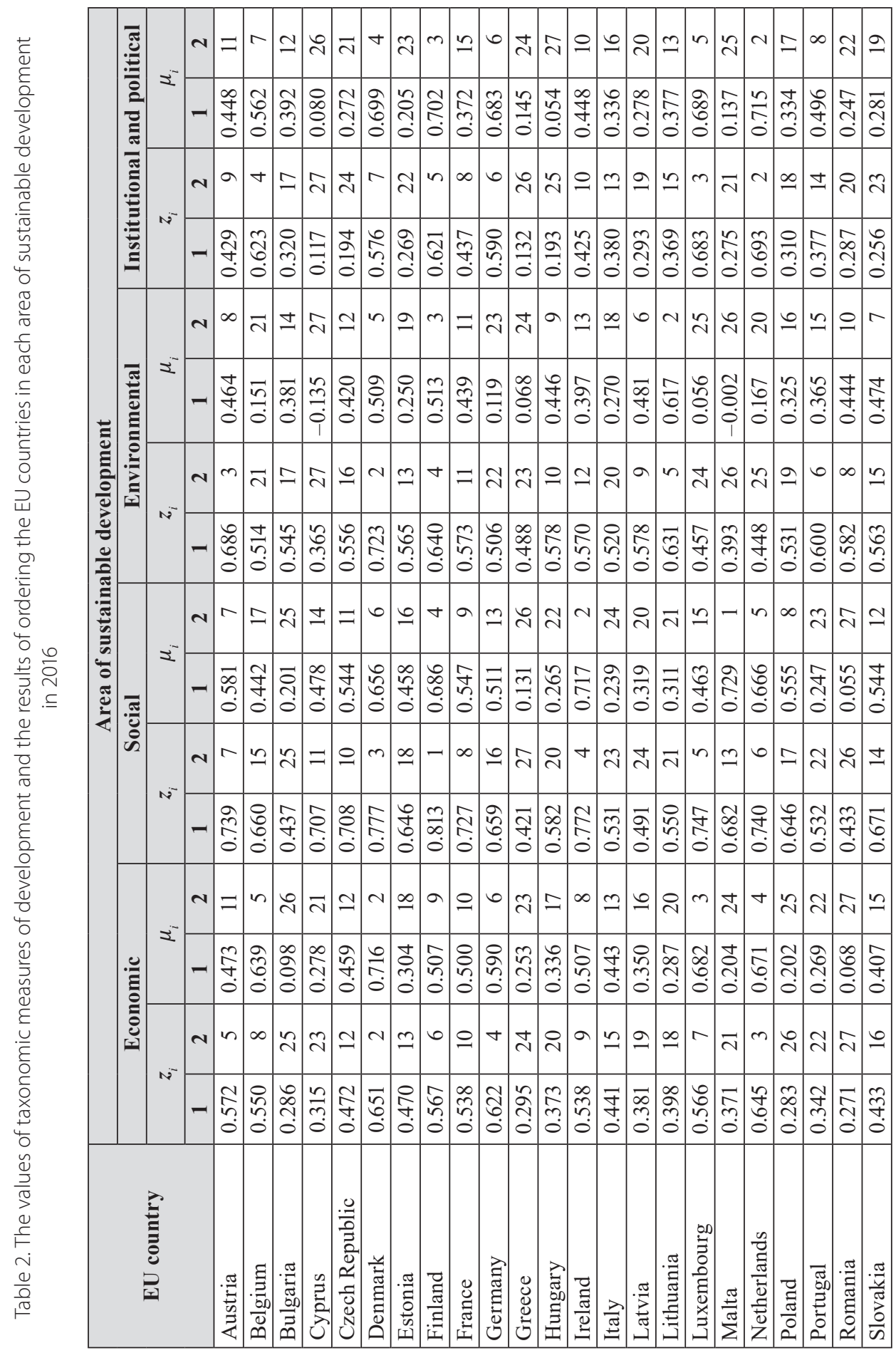




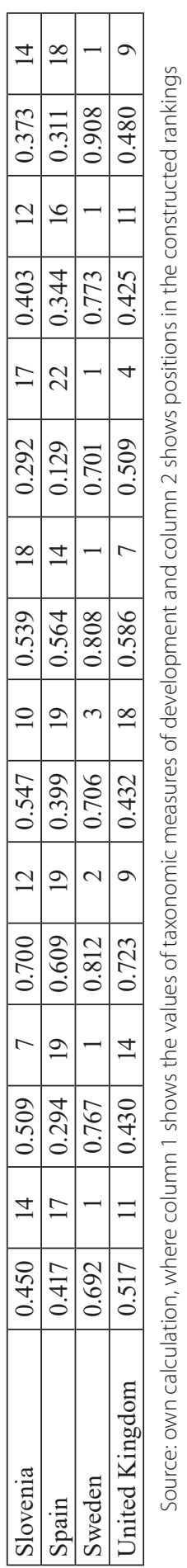

www.czasopisma.uni.lodz.pl/foe/ FOE 5(344) 2019 
Table 3. Kendall's t correlation coefficients between the positions of the countries established on the basis of synthetic classical and positional measure

\begin{tabular}{|l|c|}
\hline \multicolumn{1}{|c|}{ Area of sustainable development } & $\boldsymbol{\tau}$ Kendall \\
\hline Economic & 0.8120 \\
\hline Social & 0.6980 \\
\hline Environmental & 0.7493 \\
\hline Institutional and political & 0.7778 \\
\hline
\end{tabular}

Source: own calculation

High correlation coefficients show pretty good linear ordering compliance of countries, although there are discrepancies in the positions occupied by some of the objects. The highest value of Kendall's tau correlation coefficient was obtained for the rankings in the economic area. In this case, the differences in the occupied positions are the lowest, and for the six properties they do not exist at all. The highest differences in rankings concern three countries (Slovenia, Austria, Estonia) and they occupy positions 7, 6 and 5 respectively. The situation looks similar in the case of the institutional and political area. Only in the case of three states (France, Portugal and Bulgaria), the difference in the occupied positions exceeds four places. In the environmental area, such difference already applies to six countries, and for the social area to four ones, and in the case of the latter area the biggest differences in occupied positions can be observed for such countries as: Malta (the $13^{\text {th }}$ position in the case of the zero unitarisation method and the $1^{\text {st }}$ in the case of the measure based on Weber's median), Luxembourg ( $5^{\text {th }}$ and $15^{\text {th }}$ positions), Poland $\left(17^{\text {th }}\right.$ and $8^{\text {th }}$ positions), and the United Kingdom ( $9^{\text {th }}$ and $18^{\text {th }}$ positions).

As it was already mentioned, the high ratings of correlation coefficients are confirmed by relatively small differences in the classification of results of the EU Member States obtained with the use of the proposed methods. Larger differences are observed while analysing the value of the main characteristics of the estimated descriptive taxonomic development meters (Table 4).

By comparing the obtained results, much higher values of variation coefficients for taxonomy-based development measures based on Weber's median are observed. At the same time, the values of asymmetry coefficients are estimated in the case of the following areas: the economic, social as well as the institutional and political ones, confirming the expected higher resistance of this method to outliers. It is also worth noting that in the case of the environmental area, the signs of asymmetric coefficients are different. A positive assessment of the asymmetry coefficient obtained as a result of the application of the method of zero unitarisation to the standardisation of diagnostic characteristics means that for most countries (20) the obtained synthetic measure values are lower than the mean value. However, in the case of the synthetic measures based on Weber's median, a similar situation was observed only for 12 states. 
Table 4. Basic characteristics of descriptive taxonomic development meters established with the use of zero unitarisation method $\left(z_{i}\right)$ and based on Weber's median $\left(\mu_{i}\right)$

\begin{tabular}{|l|r|r|r|r|r|r|r|r|}
\hline \multirow{3}{*}{ Statistical description } & \multicolumn{8}{|c|}{ Area } \\
\cline { 2 - 10 } & \multicolumn{2}{|c|}{ Economic } & \multicolumn{2}{|c|}{ Social } & \multicolumn{2}{c|}{ Environmental } & $\begin{array}{c}\text { Institutional } \\
\text { and political }\end{array}$ \\
\cline { 2 - 9 } & $\boldsymbol{z}_{i}$ & $\mu_{i}$ & $\boldsymbol{z}_{i}$ & $\mu_{i}$ & $\boldsymbol{z}_{i}$ & $\mu_{i}$ & $\boldsymbol{z}_{i}$ & $\mu_{i}$ \\
\hline Mean & 0.461 & 0.416 & 0.649 & 0.460 & 0.560 & 0.328 & 0.400 & 0.408 \\
\hline Standard deviation & 0.121 & 0.183 & 0.113 & 0.183 & 0.091 & 0.198 & 0.173 & 0.213 \\
\hline Coefficient of variation [\%] & 26.313 & 43.908 & 17.454 & 39.785 & 16.179 & 60.393 & 43.283 & 52.213 \\
\hline Asymmetry & 0.112 & 0.091 & -0.624 & -0.448 & 0.393 & -0.457 & 0.483 & 0.456 \\
\hline
\end{tabular}

In the next stage of the study, to assess the situation of the surveyed EU countries in terms of all areas of sustainable development included in the study, multi-criteria taxonomy was applied. On the basis of the characteristics standardised in accordance with formulas 1-2 for zero unitarisation and in accordance with formula 3 for position normalisation, the distance matrices were established: the Euclidean distance (formula 9) and the median distance (formula 10) were used to divide the surveyed EU countries into groups characterised by similarity in all relevant areas of sustainable development. As a result, typological groups were obtained that differed in both number and composition (Table 5).

In a situation where to normalise the diagnostic features the method of zero unitarisation was used (method I), ten typological groups were obtained, out of which the most numerous one is the first group, comprising eight countries which - apart from Portugal - joined the EU in 2004. The second group consists of countries of the so-called "old Union". The third group encompasses the three countries that have belonged to the EU for over twenty years. The next three groups are two-component, and the remaining ones have formed one-element clusters.

In the case of method II, the most numerous group is also the first one, comprising thirteen EU Member States. This group consisted of countries which in majority (8) joined the European Union in 2004. The second group was formed by three countries that have been in the EU since 1957 (Belgium, Germany, the Netherlands), two of which joined the Community in 1973 (Denmark and Ireland), and Finland, which joined in 1995. In the third group, there were five countries acceding to the EU in the years 1981-2007. Another group was formed by the island states (Cyprus, Malta), which joined the EU in 2004. The other two groups have formed a one-element cluster.

The first typological group, resulting from the application of method II, is created by countries with very diverse situations in terms of the four researched areas. These are countries located both in Western and Northern Europe as well as in the South. Most of them occupy the positions in the middle of the ranking lists or lower. For example, Lithuania belongs to this group which in the environmental area 
occupies the $2^{\text {nd }}$ place, in the institutional and political one the $13^{\text {th }}$, and in the remaining areas the $20^{\text {th }}$ and $21^{\text {st }}$ positions.

Table 5. The results of multi-criteria taxonomy

\begin{tabular}{|c|l|c|l|}
\hline Group & \multicolumn{1}{|c|}{ EU countries } & Group & \multicolumn{1}{|c|}{ EU countries } \\
\hline I & $\begin{array}{l}\text { Czech Republic, Estonia, Hungary, } \\
\text { Latvia, Lithuania, Poland, Portugal, } \\
\text { Slovakia }\end{array}$ & I & $\begin{array}{l}\text { Austria, Czech Republic, Estonia, } \\
\text { France, Hungary, Italy, Latvia, } \\
\text { Lithuania, Poland, Portugal, } \\
\text { Slovenia, Slovakia, United Kingdom, }\end{array}$ \\
\hline II & $\begin{array}{l}\text { Austria, France, Germany, Italy, } \\
\text { United Kingdom }\end{array}$ & II & $\begin{array}{l}\text { Belgium, Denmark, Finland, } \\
\text { Germany, Ireland, Netherlands }\end{array}$ \\
\hline III & Belgium, Finland, Ireland & III & $\begin{array}{l}\text { Bulgaria, Greece, Hungary, Romania, } \\
\text { Spain }\end{array}$ \\
\hline IV & Cyprus, Slovenia, Spain & IV & Cyprus, Malta \\
\hline V & Denmark, Sweden & V & Luxembourg \\
\hline VI & Bulgaria, Romania & VI & Sweden \\
\hline VII & Netherland & & \\
\hline VIII & Greece & & \multicolumn{2}{|l}{} \\
\hline IX & Luxembourg & & \\
\hline X & Malta & &
\end{tabular}

Source: own calculation

The qualification of Denmark and Sweden to the same typological group according to method I (Group V) was determined by high positions taken by these countries in the rankings created for the following areas: the economic $\left(2^{\text {nd }}\right.$ and $1^{\text {st }}$ positions respectively), environmental ( $2^{\text {nd }}$ and $1^{\text {st }}$ positions $)$ and social ( $3^{\text {rd }}$ and $2^{\text {nd }}$ positions) ones and lower results in the environmental area for Denmark ( $7^{\text {th }}$ position). According to method II, Sweden created a one-element cluster because, apart from the social area ( $3^{\text {rd }}$ position), in the case of the other areas, it occupied the $1^{\text {st }}$ position. At the same time, Denmark was classified with countries located in Northern and Western Europe (Group 2).

The geographical proximity of the countries in Southern Europe is visible in the case of Group III obtained according to method II. Countries in that group in majority occupy low positions in the rankings (often below the $20^{\text {th }}$ position). Their situation is better, with the exception of Spain, only in terms of the environmental area. According to method I, the countries discussed above were qualified to different groups; however, Bulgaria and Romania (Group VI) established a separate cluster, which was predominately associated with their bad situation in the economic and social areas.

The Netherlands, according to method I, created a one-element cluster, as the country was very well evaluated in terms of the following areas: the institutional and political one ( $2^{\text {nd }}$ position), the economic one ( $3^{\text {rd }}$ position) and the social one $\left(6^{\text {th }}\right.$ position). However, in the case of the environmental area, it occupied only the 
$25^{\text {th }}$ position. Whereas pursuant to method II, this country joined the five countries in Northern Europe, which in most cases occupied high positions in terms of the following areas: the economic one (from the $2^{\text {nd }}$ to $9^{\text {th }}$ position), the social one (from the $2^{\text {nd }}$ to $17^{\text {th }}$ position) as well as the institutional and political one (from the $2^{\text {nd }}$ to $7^{\text {th }}$ position). Only in the case of the environmental area, with the exception of Finland ( $3^{\text {rd }}$ position) and Denmark ( $5^{\text {th }}$ position), the countries belonging to the second group were classified quite low (from the $13^{\text {th }}$ to $21^{\text {st }}$ position).

In both compilations, Luxembourg created alone one of the designated typological groups, and additionally, according to method I, the same situation concerned the Netherlands, Greece and Malta. They have proven to be unlike all the other analysed countries.

\section{Conclusions}

The results presented in the paper confirm the assumptions adopted at the beginning, according to which the assessment of the level of sustainable development achieved by a given country should be determined by the results achieved in each of the analysed areas of this development considered separately. This is particularly important in the case of these studies in which the development of objects is analysed through the prism of a variety of equally important areas. That is exactly the situation we face in dealing with the results of the EU countries in terms of sustainable development. It has been assumed in the paper, in accordance with the strong principle of durability of development, that these areas are equally important, and the high level of development of the examined objects will be also confirmed by the high results achieved in each of these areas. The method, which allows for the identification of the countries similar in terms of all the highlighted areas discussed in the paper, but treated separately, is multi criteria taxonomy. Its application allows us to indicate countries achieving similar results in each of the highlighted areas of sustainable development. It also allows us to avoid a situation where the average results obtained on the basis of all these areas could determine the level of development of the analysed countries. In this situation, countries such as, for example, Germany, occupying fairly high positions in the following areas: the economic one ( $4^{\text {th }}$ and $6^{\text {th }}$ positions), the social one $\left(16^{\text {th }}\right.$ and $13^{\text {th }}$ positions) as well as the institutional and political one ( $6^{\text {th }}$ position in both rankings) and classified only at the positions, respectively: $22^{\text {nd }}$ and $23^{\text {rd }}$ (depending on the method used), in the case of the environmental area, after averaging of the results would be at the $7^{\text {th }}$ position in the rankings obtained according to both proposed methods. A similar situation also applies to France or the Netherlands.

The results have also confirmed a smaller effect of outliers on the classification results of tested properties as a result of the application of standardisation us- 
ing Weber's median and the median distance for the construction of distance matrix between objects. Positional taxonomic development meter was characterised by much greater diversity and at the same time by slightly smaller asymmetry in comparison with the indicator based on zero unitarisation.

The results of the analysis of the internal structure of sustainable development presented in the paper do not only concern the decisions of quantitative measuring range of this issue (the choice and the selection of features, the applied measurement methods), also the accepted assumptions are significant as they should be in accordance with the existing theoretical achievements in this field.

\section{References}

Aiginger K., Bärenthaler-Sieber S., Vogel J. (2013), Competitiveness under New Perspectives, Working Paper, 44, https://www.econstor.eu/bitstream/10419/125699/1/WWWforEurope_WPS_ no044_MS46.pdf [accessed: 5.07.2018].

Andersen M.M. (2008), Eco-innovation - towards a taxonomy and a theory, Paper for the Druid conference, Copenhagen.

Bąk I., Szczecińska B. (2014), Analiza atrakcyjności turystycznej miast wojewódzkich, "Wiadomości Statystyczne", no. 12, pp. 80-95.

Borys T. (ed.) (2005), Wskaźniki zrównoważonego rozwoju, Wydawnictwo Ekonomia i Środowisko, Warszawa-Białystok.

Borys T., Czaja S. (2009), Badania nad zrównoważonym rozwojem w polskich ośrodkach naukowych, [in:] D. Kiełczewski (ed.), Od koncepcji ekorozwoju do ekonomii zrównoważonego rozwoju, Wydawnictwo Wyższej Szkoły Ekonomicznej w Białymstoku, Białystok.

Cheba K. (2019), Zrównoważona międzynarodowa konkurencyjność krajów Unii Europejskiej. Studium teoretyczno-empiryczne, $\mathrm{CeDeWu}$, Warszawa.

Eurostat (2018), http://ec.europa.eu/eurostat [accessed: 5.07.2018].

Guijarro F., Poyatos J.A. (2018), Designing a Sustainable Development Goal Index through a Goal Programming Model: The Case of EU-28 Countries, "Sustainability", no. 10, no. 3167, pp. $1-17$.

Hellwig Z. (1968), Zastosowanie metody taksonomicznej do typologicznego podziału krajów ze względu na poziom ich rozwoju oraz zasoby i strukturę wykwalifikowanych kadr, "Przegląd Statystyczny", R. XV(4), pp. 307-327.

Holm Olsen K., Fenhann J. (2008), Sustainable development benefits of clean development mechanism projects: A new methodology for sustainability assessment based on text analysis of the project design documents submitted for validation, "Energy Policy", no. 36(8), pp. 2819-2830.

Jeucken M. (2011), Sustainable finance and banking. The financial sector and the future of the planet, Routledge, London.

Kondyli J. (2010), Measurement and evaluation of sustainable development: A composite indicator for the islands of the North Aegean region, Greece, "Environmental Impact Assessment Review", no. 30(6), pp. 347-356.

Kukuła K. (2000), Metoda unitaryzacji zerowanej, Wydawnictwo Naukowe PWN, Warszawa.

Leonard D.R.P., Clarke K.R., Somerfield P.J., Warwick R.M. (2006), The application of an indicator based on taxonomic distinctness for UK marine biodiversity assessments, "Journal of Environmental Management", no. 78(1), pp. 52-62.

Lira J., Wagner W., Wysocki F. (2002), Mediana w zagadnieniach porządkowania obiektów wielocechowych, [in:] J. Paradysz (ed.), Statystyka regionalna w stużbie samorzadu lokalnego 
i biznesu, Internetowa Oficyna Wydawnicza Centrum Statystyki Regionalnej, Akademia Ekonomiczna w Poznaniu, Poznań, pp. 87-99.

Malina A. (2004), Wielowymiarowa analiza przestrzennego zróżnicowania struktury gospodarki Polski wedlug województw, Wydawnictwo Akademii Ekonomicznej w Krakowie, Kraków.

Malina A., Zeliaś A. (1998), Taksonomiczna analiza przestrzennego zróżnicowania jakości życia ludności w Polsce w 1994 r., "Przegląd Statystyczny", no. 44(1), pp. 11-27.

Młodak A. (2006), Analiza taksonomiczna w statystyce regionalnej, Centrum Doradztwa i Informacji Difin, Warszawa.

Nowak E. (1990), Metody taksonomiczne w klasyfikacji obiektów społeczno-gospodarczych, Polskie Wydawnictwo Ekonomiczne, Warszawa.

Panek T. (2009), Statystyczne metody wielowymiarowej analizy porównawczej, Oficyna Wydawnicza SGH, Warszawa.

Płachciak A. (2011), Geneza idei zrównoważonego rozwoju, "Ekonomia", no. 5(17), pp. 231-248.

Sébastien L., Bauler T. (2013), Use and influence of composite indicators for sustainable development at the EU-level, "Ecological Indicators", no. 35, pp. 3-12.

Sexton M.G., Barrett P.S., Lu S.L. (2008), The evolution of sustainable development, Book Section, University of Salford, Manchester.

Talukder B., Hipel K.W., Loon G. W. van (2017), Developing Composite Indicators for Agricultural Sustainability Assessment: Effect of Normalization and Aggregation Techniques, "Resources", no. 6(4), p. 66.

Velten S., Leventon J., Jager N., Newig J. (2015), What Is Sustainable Agriculture? A Systematic Review, "Sustainability", no. 7, pp. 7833-7865.

Weber A. (1909, reprint 1971), Theory of Location of Industries, Russel \& Russel, New York.

Zhao J. (2011), Towards Sustainable Cities in China. Analysis and Assessment of Some Chinese Cities in 2008, Springer, New York.

\section{Zastosowanie taksonomii wielokryterialnej do analizy porównawczej struktur zrównoważonego rozwoju}

Streszczenie: Jednym z najczęściej popełnianych błędów podczas badań nad zrównoważonym rozwojem jest rozpatrywanie zbioru cech opisujących ten rozwój w ramach jednego zbioru cech diagnostycznych. Takie podejście nie pozwala na zbadanie rzeczywistych zmian zachodzących w ramach poszczególnych ładów zrównoważonego rozwoju. Zmiany te mogą mieć zupełnie inny przebieg w przypadku wskaźników opisujących np. wymiar gospodarczy czy środowiskowy zrównoważonego rozwoju. Rozwiązaniem jest rozpatrywanie wskaźników oddzielnie dla każdego ładu, a następnie porównywanie uzyskanych wyników. W artykule zastosowano w tym celu taksonomię wielokryterialną. Do badania wykorzystano publikowane przez Eurostat wskaźniki monitorujące postęp we wdrażaniu Agendy na rzecz zrównoważonego rozwoju 2030 z lat 2008 i 2016. Otrzymane wyniki potwierdziły znaczne zróżnicowanie badanych krajów UE w zakresie poszczególnych ładów i duże ich rozwarstwienie.

Słowa kluczowe: zrównoważony rozwój, taksonomia wielokryterialna, Unia Europejska

JEL: C38, O11, P36 


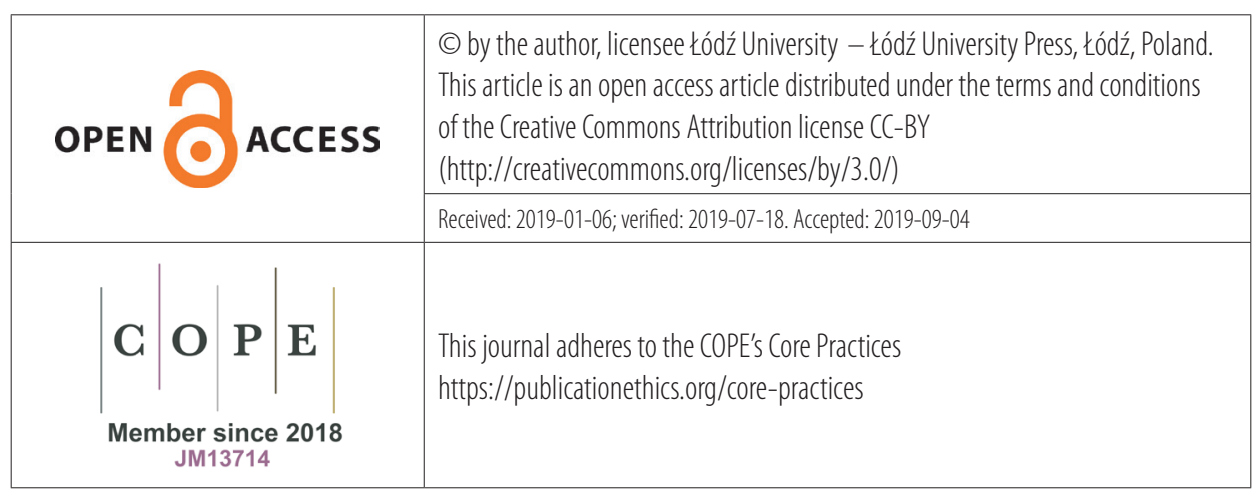

